\title{
SEBARAN PARTIKULAT (PM10) PADA MUSIM KEMARAU DI KABUPATEN TANGERANG DAN SEKITARNYA
}

\author{
Khariza Dwi Sepriani ${ }^{1}$, Ana Turyanti ${ }^{1}$ dan Mahally Kudsy ${ }^{2}$ \\ (1) Program Studi Meteorologi dan Geofisika, Fakultas MIPA, IPB, Bogor \\ (2) UPT Hujan Buatan, Badan Pengkajian dan Penerapan Teknologi, Jakarta
}

\begin{abstract}
Intisari
Pencemaran udara yang bersumber dari aktivitas antropogenik dewasa ini menjadi semakin meningkat seiring dengan berkembangnya sektor industri dan transportasi. Kabupaten Tangerang dan sekitarnya merupakan daerah industri besar di Indonesia, sehingga masyarakat di wilayah tersebut memiliki potensi terpapar pencemar udara yang tinggi. Salah satunya adalah partikulat. Sebaran partikulat dipengaruhi oleh beberapa hal diantaranya jumlah sumber emisi, serta faktor meteorologi terutama angin. Pemantauan sebaran pencemar perlu dilakukan sebagai pertimbangan untuk mengambil kebijakan terkait masalah lingkungan. Namun pemantauan pencemar terkendala oleh biaya yang besar dan ketersediaan alat di lapangan, sehingga untuk memudahkan melakukan pemantauan digunakan model sebaran pencemar. Penelitian ini bertujuan untuk mengetahui arah sebaran pencemar PM10 di wilayah Kabupaten Tangerang dan sekitarnya berdasarkan arah angin pada musim kemarau. Metode dalam penelitian ini menggunakan model Chimere yang dapat menghasilkan prakiraan pencemar udara harian, termasuk aerosol dan polutan lain. Hasil analisis menunjukkan konsentrasi PM10 tinggi di daerah sekitar Kotamadya Tangerang. Banyaknya industri dan padatnya kendaraan bermotor serta angin dominan yang menuju timur pada musim kemarau menyebabkan konsentrasi PM10 di Kota Tangerang Selatan hingga Kota Tangerang lebih tinggi daripada di sekitarnya, yakni mencapai $26-28 \mu \mathrm{g} \mathrm{m} \mathrm{m}^{-3}$. Nilai korelasi antara kecepatan angin dan konsentrasi partikulat sebesar -0.46 menunjukkan kecepatan angin cukup mempengaruhi tingkat konsentrasi PM10.
\end{abstract}

\begin{abstract}
Air pollution originating from anthropogenic activities nowadays be increased along with industry development and transportation sector. Tangerang District and its surrounding areas are a large industrial area in Indonesia, so people in the region have a high potential for exposure to air pollutant. Particulate is one of the pollutions. Monitoring the pollutant dispersion is necessary to be conducted as a consideration to take a policy related to environmental issues. However, pollutant monitoring constrained by cost and availability of tools in the field, so the model is used to make pollutant monitoring easier. This study aims to determine the direction of PM10 pollutant dispersion in Tangerang and the surrounding area based the dominant wind direction in the dry season. The method in this study uses Chimere model that can generate daily air pollution forecast. Result shows high PM10 concentration around Tangerang City. High number of industries and vehicles and also the dominant winds eastward in the dry season led to a concentration of PM10 in Tangerang City until South Tangerang City higher than around, namely reached $26-28 \mu \mathrm{g} \mathrm{m}^{-3}$. Correlation value between wind speed and particulate concentration is -0.46 indicated that the wind speed has considerable influence the level of PM10 concentrations.
\end{abstract}

Kata kunci: PM10, Kabupaten Tangerang, Sebaran pencemar 


\section{PENDAHULUAN}

Udara merupakan komponen penting dalam kehidupan sehingga perlu dipelihara kualitasnya agar dapat memberikan daya dukung yang optimal bagi makhluk hidup. Pencemaran udara saat ini semakin menunjukkan kondisi yang membahayakan. Sumber pencemaran yang berasal dari aktivitas antropogenik antara lain industri, transportasi, perumahan, serta perkantoran. Pertumbuhan penduduk yang turut memicu peningkatan pembangunan seperti industri dapat memberikan dampak positif bagi peningkatan pendapatan daerah, namun disisi lain juga akan memberikan kontribusi negatif, salah satunya berupa pencemaran udara.

Kabupaten Tangerang dan sekitarnya merupakan wilayah industri besar di Indonesia. Kemajuan sektor industri di wilayah ini terbilang cukup pesat sehingga masyarakat memiliki potensi terpapar oleh pencemar yang tinggi. Meningkatnya jumlah masyarakat yang beraktivitas dapat meningkatkan emisi yang dihasilkan dari kegiatan antropogenik baik dalam sektor industri maupun transportasi. Berdasarkan hasil penelitian yang dilakukan oleh Noor dan Sofyan (2012) menyebutkan bahwa emisi tertinggi dari bidang transportasi dihasilkan oleh Kabupaten Tangerang diikuti oleh Jakarta Selatan dan Kota Tangerang.

Salah satu zat pencemar yang cukup banyak dihasilkan oleh kegiatan antropogenik adalah partikulat (Particulate Matter (PM)). Partikulat yang berukuran kurang dari $10 \mu \mathrm{m}$ disebut dengan PM10. Sekitar $50 \%$ dari total emisi debu di atmosfer merupakan PM10. Emisi ini berkontribusi secara signifikan bagi pemanasan atmosfer, tidak hanya menyebar tetapi juga menyerap radiasi surya (Haywood dan Boucher 2000). Sebaran PM10 di udara dipengaruhi oleh kondisi sumber pencemar serta oleh proses fisik dan kimiawi pencemar tersebut di atmosfer. Bahan pencemar ini akan terbawa oleh angin dan akan berakumulasi di tempat tujuan arah angin tersebut. Pencemar partikulat apabila terhirup dalam jumlah banyak dalam waktu yang lama dapat menyebabkan kerusakan fungsi organ pernapasan. Pengaruh musim juga dapat meningkatkan konsentrasi PM10 di suatu wilayah. Berdasarkan penelitian dari Muhaimin (2014) konsentrasi total partikulat pada musim kemarau lebih tinggi daripada ketika musim hujan, hal ini karena pada musim hujan zat pencemar yang ada di atmosfer mengalami proses penghilangan atau pengurangan akibat adanya pencucian udara oleh hujan (Puspitasari 2011), sehingga polutan akan terlihat lebih jelas.

Pemantauan sebaran pencemar perlu dilakukan untuk memprediksi arah sebaran polutan dari suatu sumber terutama pencemar yang berupa partikulat. Namun pemantauan pencemar terkendala oleh biaya yang besar dan ketersediaan alat di lapangan, sehingga untuk mempermudah digunakan model sebaran polutan, salah satunya adalah Chimere. Tujuan dari penelitian ini adalah untuk mengetahui arah sebaran pencemar PM10 di wilayah Kabupaten Tangerang pada musim kemarau.

\section{DATA DAN METODE PENELITIAN}

Data yang digunakan adalah data emisi antropogenik global dan data angin global pada koordinat $105^{\circ} \mathrm{BT}-114^{\circ} 57^{\prime} 12^{\prime \prime}$ BT dan $5^{\circ} 33^{\prime} 36^{\prime \prime}$ LS - $8^{\circ} 30^{\prime}$ LS dengan ketinggian tiap level adalah sekitar 25 m AGL (meter Above Ground Level). Data diperoleh dari website www.Imd.polytechnique.fr/chimere/download.php untuk data emisi antropogenik dan www.rda.ucar.edu/datasets/ds083.2/index.htm/ untuk data angin global. Selain itu, validasi dengan kondisi angin daerah menggunakan data arah dan kecepatan angin dari Stasiun Meteorologi Curug Budiarto. Seluruh data yang digunakan dimulai dari tanggal 28 Juli hingga 1 Agustus 2013.

\subsection{Pengolahan Data dengan Model Chimere}

Sebelum melakukan running model Chimere, source code dan data dari model Chimere diunduh terlebih dahulu. Data yang diambil merupakan data emisi untuk bulan Juli dan Agustus. Input untuk model Chimere ini berasal dari data emisi global dan data meteorologi global yang merupakan output dari MM5. Data emisi sudah termasuk boundary dan initial condition yaitu berupa chemical boundary dan initial concentration sehingga hasil yang tergambarkan tidak hanya dari sumber titik, namun juga dari kimia atmosfer. Parameterisasi yang dilakukan merupakan penentuan kondisi meteorologi berupa suhu, kelembaban, angin, dan tekanan udara.

Menentukan jangka waktu yang akan digunakan, yaitu dimulai dari time $=1$ hingga time $=$ 121. Domain diperoleh dengan menentukan koordinat kartesian (nzdoms dan nmdoms) dalam parameter chimere.par. Running chimere-domain.sh setelah menentukan koordinat untuk membuat semua data landuse yang diperlukan untuk deposisi dan emisi biogenik MEGAN terdapat pada grid domain sehingga data landuse akan secara 
otomatis diperhitungkan. Resolusi yang digunakan 1 $\mathrm{KM} \times 1 \mathrm{KM}$.

\subsection{Visualisasi Output Model}

Hasil keluaran model berupa file output.ctl yang berisi emisi antropogenik dari wilayah domain. Visualisasi dilakukan dengan perangkat lunak GrADS dengan menentukan waktu yang diperlukan, yaitu setiap enam jam mulai dari $t=1$ yang menunjukkan pukul 00 UTC pada tanggal 28 Juli 2013 hingga $t=115$ yang menunjukkan pukul 18 UTC pada tanggal 1 Agustus 2013. Perangkat lunak GrADS juga digunakan untuk memperoleh nilai rataan konsentrasi PM10 dan kecepatan angin dalam wilayah kajian.

\subsection{Analisis Data Angin}

Data arah dan kecepatan angin aktual diperoleh dari Stasiun Meteorologi Curug Budiarto Tangerang. Data kecepatan angin berupa data per jam selama enam bulan dan dirata-ratakan menjadi data harian. Sementara itu data arah angin berupa data harian yang dapat langsung digunakan. Data ini kemudian diolah dengan model WRPLOT dan menghasilkan diagram windrose.

\subsection{Metode Penentuan Koefisien Korelasi}

Penentuan koefisien korelasi digunakan untuk mencari hubungan antara dua variabel dengan nilai berkisar antara -1 hingga +1 . Hubungan tersebut menunjukkan perbandingan terbalik jika nilai yang diperoleh negatif dan berbanding lurus jika bernilai positif. Penentuan koefisien korelasi dapat dituliskan sebagai berikut (Aunuddin 2005) :

$$
r=\frac{\sum\left(x_{i}-\bar{x}\right)\left(y_{i}-\bar{y}\right)}{\sqrt{\sum\left(x_{i}-\bar{x}\right)^{2} \sum\left(y_{i}-\bar{y}\right)^{2}}}
$$

$$
\begin{array}{ll}
\text { Keterangan : } \\
r & =\text { koefisien korelasi } \\
x_{i} & =\text { variabel pertama } \\
\bar{x} & =\text { rataan variabel pertama } \\
y_{i} & =\text { variabel kedua } \\
\bar{y} & =\text { rataan variabel kedua }
\end{array}
$$

\section{HASIL PENELITIAN DAN PEMBAHASAN}

\subsection{Kondisi Meteorologi Tangerang}

Berdasarkan data yang diperoleh dari Stasiun Meteorologi Budiarto, Curug dalam rentang tahun
2009 - 2013, temperatur udara rata-rata $26.7^{\circ} \mathrm{C}$, rata-rata temperatur udara bulanan tertinggi pada bulan April dan September yaitu $27.1^{\circ} \mathrm{C}$ dan ratarata temperatur udara bulanan terendah pada bulan Januari yaitu $26^{\circ} \mathrm{C}$. Rata-rata kelembaban udara sekitar $81 \%$ dengan intensitas radiasi $60 \%$. Ratarata curah hujan bulanan tertinggi terjadi pada bulan Januari yaitu $302.46 \mathrm{~mm}$ dan terendah pada bulan Agustus yaitu $103.62 \mathrm{~mm}$, sedangkan rata-rata curah hujan dalam 5 tahun adalah $191 \mathrm{~mm}$. Ratarata kecepatan angin dalam setahun adalah $5 \mathrm{~m} \mathrm{~s}^{-1}$.

Sebagian besar wilayah Indonesia pada tahun 2013 memasuki musim kemarau mulai sekitar bulan April, Mei, dan Juni (BMKG 2013). Diagram curah hujan pada Gambar 1 menunjukkan rata-rata curah hujan bulanan dalam rentang lima tahun untuk menggambarkan masa musim kemarau. Berdasarkan pola curah hujan dari tahun 2009 menunjukkan curah hujan mulai menurun dari bulan Mei dan meningkat kembali di bulan Oktober.

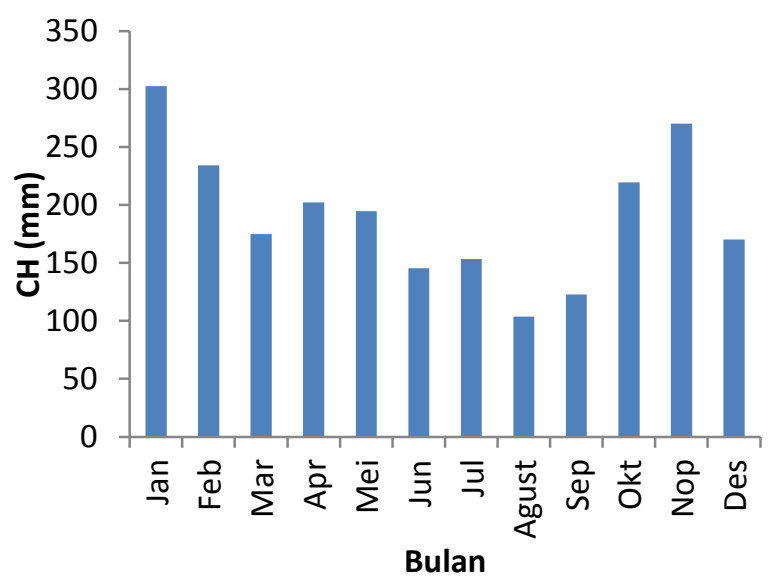

Gambar 1 Rataan tingkat curah hujan bulanan selama tahun 2009 hingga 2013

Arah angin pada musim kemarau ini digambarkan dengan menggunakan diagram windrose hasil keluaran perangkat lunak WRPLOT View 7.0.0. Data yang digunakan adalah data angin Stasiun Meteorologi Curug Budiarto Tangerang selama dua tahun (2012-2013) pada musim kemarau dan hujan. 


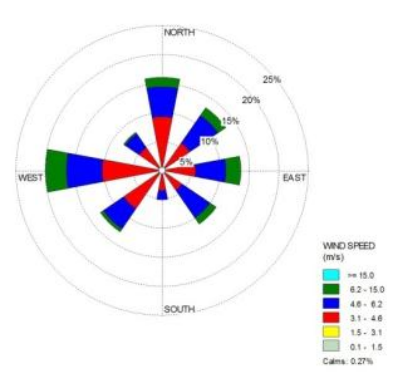

(a)

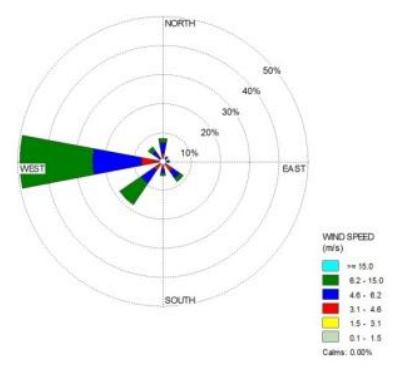

(b)
Gambar 2 Diagram windrose sebaran angin musim kemarau (a) dan musim hujan (b)

Gambar 2(a) mewakili kondisi arah dan kecepatan angin pada musim kemarau dan Gambar 2(b) pada musim hujan di Kabupaten Tangerang dan sekitarnya. Berdasarkan gambar tersebut tidak begitu terlihat arah angin dominan selama bulan Mei - Oktober yang merupakan musim kemarau. Namun angin dari arah Barat terlihat lebih sering terjadi dengan frekuensi sebanyak $20 \%$. Kecepatan angin bervariasi dalam bulan kering ini. Kecepatan angin tertinggi yang tercatat adalah sebesar $9.7 \mathrm{~m} \mathrm{~s}^{-1}$. Sedangkan kecepatan angin dominan sebesar $4 \mathrm{~m}$ $\mathrm{s}^{-1}$. Arah angin bulan November - April terlihat dominan dari arah barat dengan frekuensi mencapai $50 \%$ dan kecepatan angin tertinggi sebesar $11.5 \mathrm{~m}$ $\mathrm{s}^{-1}$. Faktor lokal seperti topografi mempengaruhi arah angin. Wilayah Barat Kabupaten Tangerang berbatasan dengan Kabupaten Serang yang berada di dataran tinggi sehingga angin akan bergerak menuju wilayah Kabupaten Tangerang yang lebih rendah. Topografi Kabupaten Tangerang berbatasan dengan Laut Jawa di sebelah Utara sehingga faktor angin lokal yaitu angin darat laut juga mempengaruhi arah angin.

\subsection{Sebaran Konsentrasi PM10 Hasil Analisis Model Chimere}

Sebaran PM10 di wilayah Kabupaten Tangerang pada musim kemarau diwakili oleh periode 28 Juli 2013 - 1 Agustus 2013. Data sebaran konsentrasi ini merupakan data emisi antropogenik global yang diambil pada ketinggian 25 m AGL. Lampiran 1 - 5 menunjukkan sebaran PM10 per 6 jam hasil model Chimere dengan daerah kajian yang diperluas hingga Kota Tangerang. Waktu yang digunakan dimulai pada pukul 00 UTC yang menunjukkan waktu dimulainya aktivitas masyarakat hingga 18 UTC ketika aktivitas masyarakat cenderung menurun. Perluasan tampilan untuk melihat sebaran yang lebih luas.

Berdasarkan arah angin dalam rentang waktu pengamatan selama lima hari, partikulat menyebar menuju arah Timur dan Tenggara. Wilayah Timur Kabupaten Tangerang merupakan Kota Tangerang sementara di Tenggara merupakan Kota Tangerang Selatan. Partikulat menyebar menuju Kota Tangerang dan Tangerang Selatan disebabkan oleh arah angin yang bergerak menuju Timur dan Tenggara.

Gambar 3 menunjukkan pergerakan partikulat menuju arah angin. Angin bertiup cukup kencang dari Utara dan Barat Laut kemudian berangsur menurun ketika berada di Kecamatan Kosambi, Sepatan, dan Kota Tangerang yang berada di Timur sehingga terlihat penumpukan partikulat dengan konsentrasi berkisar antara $12-14 \mathrm{\mu g} \mathrm{m}^{-3}$.

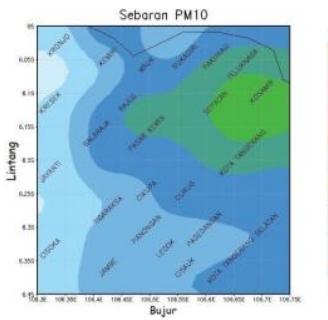

(a)

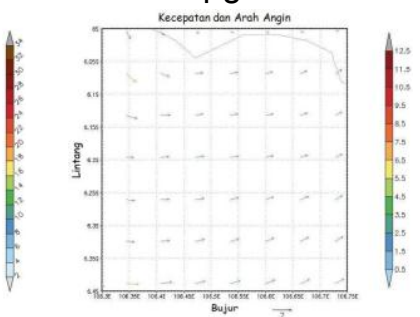

(b)
Gambar 3 Sebaran konsentrasi PM10 $\left(\mu \mathrm{g} \mathrm{m}^{-3}\right)(\mathrm{a})$ dan pola angin (b) tanggal 28 Juli 2013 pukul 06 UTC

Pergerakan angin ini dipengaruhi faktor lokal berupa angin laut yang berasal dari Laut Jawa di Utara bergerak menuju daratan yang lebih panas pada siang hari. Ketika malam hari angin bertiup menuju laut di Utara dengan sebagian berbelok menuju Kota Tangerang dan Tangerang Selatan. Hal ini dikarenakan suhu permukaan di wilayah perkotaan lebih tinggi dengan kondisi penduduk yang padat disertai dengan aktivitas penduduk yang tinggi pula sehingga memungkinkan kondisi atmosfer permukaan menjadi tidak stabil dan terjadi turbulensi yang disertai dengan percampuran PM10 di permukaan dan menyebabkan tingginya konsentrasi di Kota Tangerang dan Kota Tangerang Selatan.

Kecepatan angin mempengaruhi tingkat konsentrasi partikulat. Ketika angin bertiup kencang, partikulat akan tersebar lebih luas dan menurunkan konsentrasinya. Begitu pula sebaliknya, ketika angin bertiup lemah, partikulat tidak tersebar dan 
menumpuk di satu lokasi sehingga konsentrasinya meningkat. Lampiran 5 menunjukkan kecepatan angin yang lemah akan meningkatkan konsentrasi partikulat. Selain itu faktor curah hujan saat hari pengamatan juga mempengaruhi konsentrasi partikulat. Seperti pada hari ke tiga pada tanggal 30 Juli 2013 (Gambar 4) konsentrasi rendah hingga di bawah $2 \mu \mathrm{g} \mathrm{m}^{-3}$ di Kecamatan Cisoka dan Jayanti akibat angin yang bertiup kencang dan hujan yang mencapai $62.4 \mathrm{~mm}$ berdasarkan data online dari website BMKG (Lampiran 6), sehingga terjadi pencucian polutan.

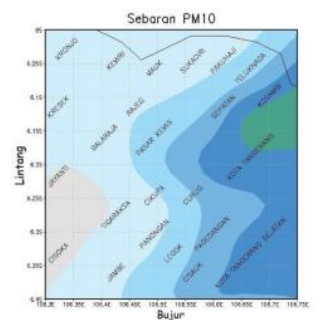

(a)

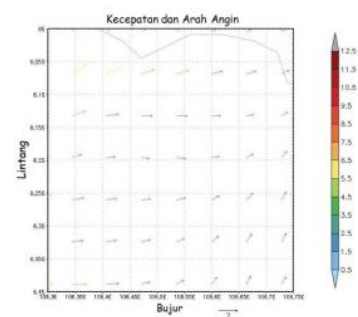

(b)
Gambar 4 Sebaran konsentrasi PM10 $\left(\mu \mathrm{g} \mathrm{m}^{-3}\right)(\mathrm{a})$ dan pola angin (b) tanggal 30 Juli 2013 pukul 18 UTC

Konsentrasi tertinggi per hari selama 5 hari pengamatan tercatat mencapai kisaran $26-28 \mu \mathrm{g}$ $\mathrm{m}^{-3}$ dengan rataan $11.7 \mu \mathrm{g} \mathrm{m}^{-3}$ pada hari ke lima tanggal 1 Agustus 2013 pukul 06 UTC (Gambar 5). Penumpukan PM10 terlihat jelas di Kota Tangerang Selatan dan Kota Tangerang. Curah hujan yang rendah yaitu hanya $1.3 \mathrm{~mm}$ disertai dengan kecepatan angin yang lemah menjadi penyebab meningkatnya konsentrasi pada hari tersebut. Selain itu pola angin menunjukkan angin yang bertiup lemah tersebut mengarah ke Kota Tangerang Selatan Kota Tangerang Selatan.

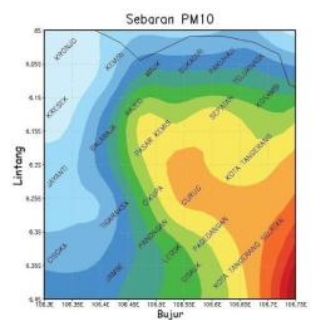

(a)

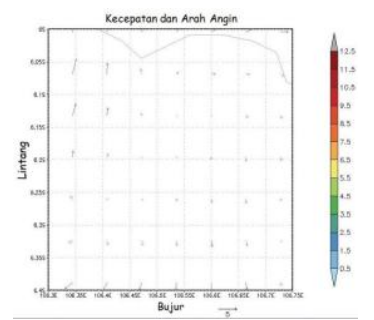

(b)
Gambar 5 Sebaran konsentrasi PM10 $\left(\mu \mathrm{g} \mathrm{m}^{-3}\right)(\mathrm{a})$ dan pola angin (b) tanggal 1 Agustus 2013 pukul 06 UTC
Menurut PP No. 41 Tahun 1999 tentang Pengendalian Pencemaran Udara, baku mutu udara ambien nasional untuk PM10 selama 24 jam adalah sebesar $150 \mathrm{\mu g} \mathrm{m}^{-3}$. Hasil pemantauan konsentrasi di wilayah Kabupaten Tangerang dan sekitarnya menunjukkan konsentrasi PM10 masih di bawah baku mutu udara ambien.

Salah satu sumber emisi PM10 antropogenik berasal dari industri di wilayah Kabupaten Tangerang dan sekitarnya. Jumlah industri di Kabupaten Tangerang sebanyak 692 industri (BPS 2013), sedangkan di Kota Tangerang berjumlah 665 industri skala besar (Pemerintah Kota Tangerang 2013). Padatnya wilayah Kota Tangerang menyebabkan suhu permukaan lebih tinggi sehingga atmosfer permukaan menjadi tidak stabil dan terjadi pencampuran PM10 dengan atmosfer. Emisi antropogenik dapat berasal dari Kabupaten Tangerang, namun arah angin yang menuju Kota Tangerang dan Tangerang Selatan menyebabkan PM10 terbawa dan terakumulasi sehingga berpotensi mengalami peningkatan di Kota Tangerang. Selain itu, aktivitas masyarakat baik industri maupun transportasi di Kota Tangerang dan Tangerang Selatan juga ikut berkontribusi meningkatkan konsentrasi PM10 di wilayah ini. Secara umum, dalam waktu lima hari pengamatan terlihat konsentrasi PM10 saat pagi hari cukup rendah kemudian meningkat tinggi saat siang hari sekitar pukul 13.00 WIB (pukul 06 UTC). Ketika menjelang malam hingga tengah malam konsentrasi PM10 kembali mengalami penurunan. Hal ini dikarenakan aktivitas masyarakat yang menghasilkan emisi PM10 dilakukan pada siang hari. Berdasarkan data yang diperoleh dari BLHD Kabupaten Tangerang tahun 2012 - 2013, konsentrasi PM10 tertinggi pada udara ambien tercatat pada salah satu perusahaan di Kecamatan Balaraja, yaitu mencapai $310 \mu \mathrm{g} \mathrm{m}^{-3}$. Nilai tersebut sudah melebihi nilai baku mutu udara ambien nasional 24 jam.

Massa PM10 lebih berat daripada polutan gas, sehingga ketika terjadi percampuran PM10 akan langsung jatuh kembali ke permukaan. Keberadaan partikulat di atmosfer cukup dinamis sehingga konsentrasinya dapat meningkat atau pun menurun. Perubahan konsentrasi PM10 di atmosfer ini dipengaruhi pula oleh waktu tinggalnya (residence time). Waktu tinggal partikulat di atmosfer bergantung pada ukurannya. Efek dari gravitasi dapat menyebabkan partikel berukuran kasar seperti 
PM10 secara cepat dapat dihilangkan dari atmosfer oleh sedimentasi (waktu tinggal antara beberapa menit dan beberapa jam). Selain itu partikel dalam bentuk yang lebih kecil dapat dengan cepat bertransformasi menjadi partikulat berukuran kasar oleh proses koagulasi. Waktu tinggal tertinggi di atmosfer (dapat mencapai beberapa minggu) adalah berupa partikulat yang berakumulasi, sehingga dapat dengan mudah dibawa oleh angin hingga ribuan kilometer dari wilayah terbentuknya (Perrino 2010).

\subsection{Analisis Hubungan Kecepatan Angin dengan Konsentrasi PM10}

Berdasarkan hasil yang diperoleh maka dapat diketahui bahwa pada saat tertentu terjadi penurunan konsentrasi PM10. Faktor penyebab penurunan konsentrasi tersebut dapat dipengaruhi oleh kecepatan angin yang bertiup di wilayah tersebut. Kecepatan angin mempengaruhi distribusi pencemar, konsentrasi pencemar akan berkurang jika angin kencang dan membagikan pencemar secara mendatar dan tegak lurus. Rataan kecepatan angin dalam luasan wilayah yang tercakup dalam koordinat digunakan untuk menganalisis hubungan antara konsentrasi PM10 dengan faktor kecepatan angin (Lampiran 7). Analisis yang dilakukan mencakup keseluruhan waktu yang digunakan, yaitu dimulai dari tanggal 28 Juli 2013 pukul 00 UTC hingga 1 Agustus 2013 pukul 18 UTC.

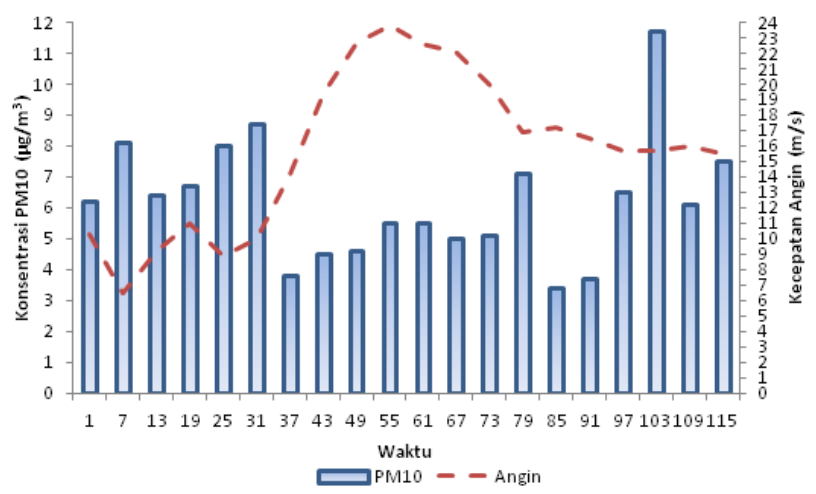

Gambar 6 Hubungan antara kecepatan angin dengan konsentrasi PM10 selama lima hari

Terlihat dari Gambar 6 konsentrasi cukup tinggi pada hari pertama hingga tengah hari kedua yaitu pada $t=1$ hingga $t=31$. Rata-rata konsentrasi pada waktu tersebut hingga mencapai $9 \mu \mathrm{g} \mathrm{m}$. Tingginya konsentrasi PM10 tersebut disertai dengan kecepatan angin yang tidak terlalu kencang. Nilai tertinggi dari rata-rata kecepatan angin sebesar $24 \mathrm{~m} \mathrm{~s}^{-1}$, sedangkan mulai dari tengah hari kedua hingga hari keempat, yaitu $t=37$ hingga $t=91$ terjadi peningkatan kecepatan angin hingga $24 \mathrm{~m} \mathrm{~s}^{-1}$ yang mengakibatkan penurunan konsentrasi PM10 hingga tercatat nilai terkecil sebesar $4 \mathrm{\mu g} \mathrm{m}^{-3}$. Terjadi peningkatan konsentrasi PM10 yang cukup signifikan pada $t=103$ hingga mencapai $11.5 \mathrm{\mu g} \mathrm{m}^{-3}$ dengan rata-rata kecepatan angin $16 \mathrm{~m} \mathrm{~s}^{-1}$.

Berdasarkan hasil yang diperoleh, maka didapatkan nilai korelasi antara nilai rataan kecepatan angin dengan rataan konsentrasi PM10. Nilai korelasi yang diperoleh adalah -0.46. Hasil tersebut juga tidak berbeda jauh dengan hasil analisis yang dilakukan oleh Turyanti dan Santikayasa (2007) untuk wilayah Jakarta dengan nilai korelasi antara fluktuasi kecepatan angin dan konsentrasi partikulat sebesar -0.47. Selain itu Chaloulakou et al. (2003) menyebutkan PM10 memiliki korelasi negatif dengan kecepatan angin, yaitu sebesar -0.43 . Nilai tersebut menunjukkan hubungan berbanding terbalik antara nilai rataan kecepatan angin dengan rataan konsentrasi PM10, yaitu untuk menggambarkan semakin kencang tiupan angin maka konsentrasi PM10 akan berkurang. Hal ini juga sesuai dengan hasil penelitian Maraziotis et al. (2008) yang menyebutkan bahwa terdapat korelasi antara konsentrasi partikulat dengan kecepatan angin. Nilai korelasi tersebut tergolong dalam kriteria korelasi cukup (Sarwono 2006), yaitu tingkat konsentrasi PM10 tidak hanya dipengaruhi oleh kecepatan angin, namun juga oleh faktor-faktor lainnya, seperti residence time, suhu, dan intensitas hujan yang terjadi pada hari tersebut. Menurut Al-Jallad et al. (2013), korelasi positif antara PM10 dan suhu udara menunjukkan pengaruh temperatur pada proses konversi pembentukan partikulat baru dari gas menjadi partikel. Umumnya, konsentrasi partikulat lebih tinggi sepanjang hari yang panas dikarenakan tingginya aktifitas photochemical pada hari dengan intensitas radiasi yang tinggi (Chaloulakou et al. 2003).

\section{KESIMPULAN DAN SARAN}

\subsection{Kesimpulan}

Sebaran pencemar PM10 di wilayah Kabupaten Tangerang dan sekitarnya secara garis besar terlihat mengarah ke Kota Tangerang yang berada di bagian Timur. Hal ini disebabkan karena arah angin dominan pada musim kemarau tahun 2013 menuju ke Timur. Konsentrasi tertinggi 
mencapai 26-28 $\mathrm{\mu g} \mathrm{m}^{-3}$ dengan rataan $11.5 \mu \mathrm{g} \mathrm{m}$ pada tanggal 1 Agustus 2013 pukul 06 UTC yang mencakup Kota Tangerang dan Kota Tangerang Selatan. Nilai tertinggi ini menunjukkan konsentrasi PM10 di wilayah Kabupaten Tangerang dan sekitarnya masih di bawah baku mutu nasional, yaitu $150 \mu \mathrm{g} \mathrm{m}^{-3}$ dalam waktu $24 \mathrm{jam}$. Secara umum, konsentrasi PM10 saat pagi hari cukup rendah kemudian meningkat tinggi saat siang hari sekitar pukul 13.00 WIB (pukul 06 UTC). Ketika menjelang malam hingga tengah malam konsentrasi PM10 kembali mengalami penurunan. Nilai korelasi antara kecepatan angin dan konsentrasi PM10 sebesar 0.46 dan menunjukkan adanya hubungan berbanding terbalik di antara dua variabel dan tergolong dalam kriteria korelasi cukup.

\subsection{Saran}

Saran untuk penelitian selanjutnya adalah membandingkan kondisi sebaran PM10 musim kemarau dan musim hujan. Arah sebaran PM10 yang dominan menuju Kota Tangerang dan Kota Tangerang Selatan dapat menjadi pertimbangan bagi pemerintah setempat untuk mengambil kebijakan terkait kondisi lingkungan, seperti pengelolaan tata ruang dengan ditambahkan ruang terbuka hijau pada wilayah ini.

\section{DAFTAR PUSTAKA}

Al-Jallad, F., E. Al-Katheeri, M. Al-Omar. 2013. Concentrations of particulate matter and their relationship with meteorological variables. J. Sustainable Environment Research. 23(3) : 191-198

Aunuddin. 2005. Statistika Rancangan dan Analisis Data. IPB Press, Bogor

[BMKG] Badan Meteorologi, Klimatologi, dan Geofisika. 2013. Press Release Prakiraan Musim Kemarau 2013 di Indonesia. Jakarta (ID) : BMKG.

[BMKG] Badan Meteorologi, Klimatologi, dan Geofisika. 2014. Data Iklim Periode 28 Juli 2013 - 1 Agustus 2013. BMKG [Internet]. [diunduh 2014 November 28]. Tersedia pada : http://dataonline.bmkg.go.id

[BPLHD] Badan Pengelola Lingkungan Hidup Daerah. 2013. Laporan Rutin Perusahaan Upaya Pengelolaan Lingkungan Hidup (UPL) /
Upaya Pemantauan Lingkungan Hidup (UKL) Tahun 2010-2013. BPLHD, Tangerang

[BPS] Badan Pusat Statistik. 2013. Kabupaten Tangerang dalam Angka 2013. Badan Pusat Statistik Kabupaten Tangerang, Tangerang

Chaloulakou, A., P. Kassomenos, N. Spyrellis, P. Demokritou, \& P. Koutrakis. 2003. Measurements of PM10 and PM2,5 particle concentrations in Athens, Greece. J. Atmospheric Environment. 37 : 649-660

Haywood, James dan Boucher, Olivier. 2000. Estimates of the direct and indirect radiative forcing due to tropospheric aerosol : A review; Rev. Geophysic. 38(4) 513-543.

Maraziotis, E., L. Sarotis, C. Marazioti, \& P. Marazioti. 2008. Statistical analysis of inhalable (PM10) and fine particles (PM2,5) concentrations in urban region of Patras, Greece. Global NEST Journal 10 (2) : 123131.

Muhaimin. 2014. Permodelan dispersi polutan udara dari aktivitas PLTU Cirebon pada musim kemarau dan hujan serta penggunaan 2 cerobong asap [tesis]. Universitas Gajah Mada, Yogyakarta

Noor HAA dan Sofyan A. 2012. Inventarisasi emisi pencemaran udara dan gas rumah kaca di Jabodetabek dengan menggunakan metode SIG (Sistem Informasi Geografis) [skripsi]. Institut Teknologi Bandung, Bandung

Perrino, Cinzia. 2010. Atmospheric Particulate Matter, dalam : Proceedings of C.I.S.B. Minisymposium. Rome (IT) : C.NR. Institute of Atmospheric Pollution.

Pemerintah Kota Tangerang. 2013. Laporan Status Lingkungan Hidup Daerah Kota Tangerang Tahun 2012. Pemerintah Kota Tangerang, Tangerang

PP No. 41 Tahun 1999 tentang Pengendalian Pencemaran Udara.

Puspitasari, Anita Dwi. 2011. Pola spasial pencemaran udara dari sumber pencemar PLTU dan PLTGU Muara Karang [skripsi]. Universitas Indonesia, Depok

Sarwono, Jonathan. 2006. Metode Penelitian Kuantitatif dan Kualitatif. Graha IImu, Yogyakarta

Turyanti, Ana. dan Santikayasa, I Putu. 2007. Analisa pola unsur meteorologi dan konsentrasi polutan di udara ambien (Studi 
kasus Kota Jakarta dan Bandung). J. Agromet

Indonesia 20 (2): 25-37. 
LAMPIRAN

Lampiran 1 Sebaran konsentrasi PM10 $\left(\mu \mathrm{g} \mathrm{m}^{-3}\right)(\mathrm{a})$ dan pola angin (b) tanggal 28 Juli 2013 tiap enam jam di Kabupaten Tangerang
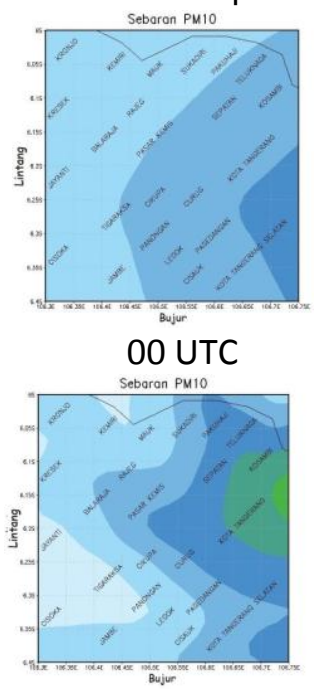

12 UTC

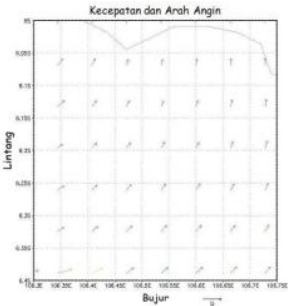

OO UTC

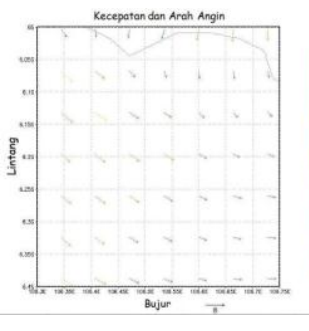

12 UTC

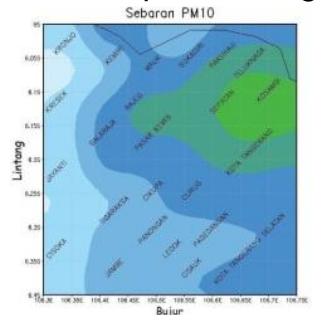

06 UTC

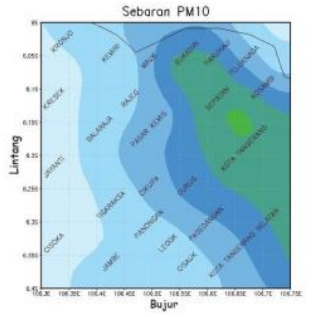

18 UTC

(a)

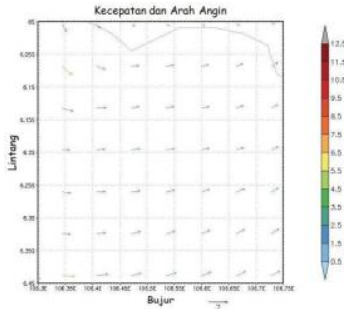

06 UTC

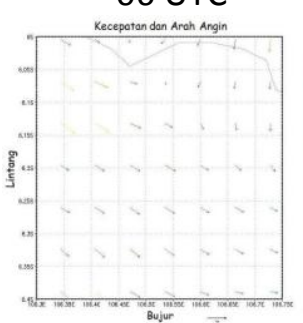

18 UTC
Lampiran 2 Sebaran konsentrasi PM10 $\left(\mu \mathrm{g} \mathrm{m}^{-3}\right)$ (a) dan pola angin (b) tanggal 29 Juli 2013 tiap enam jam di Kabupaten Tangerang
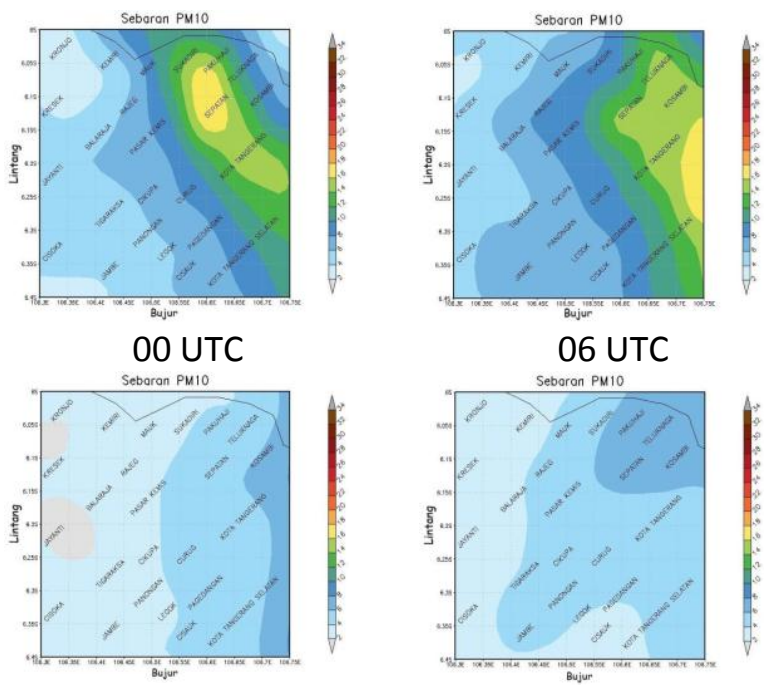

12 UTC

(a)
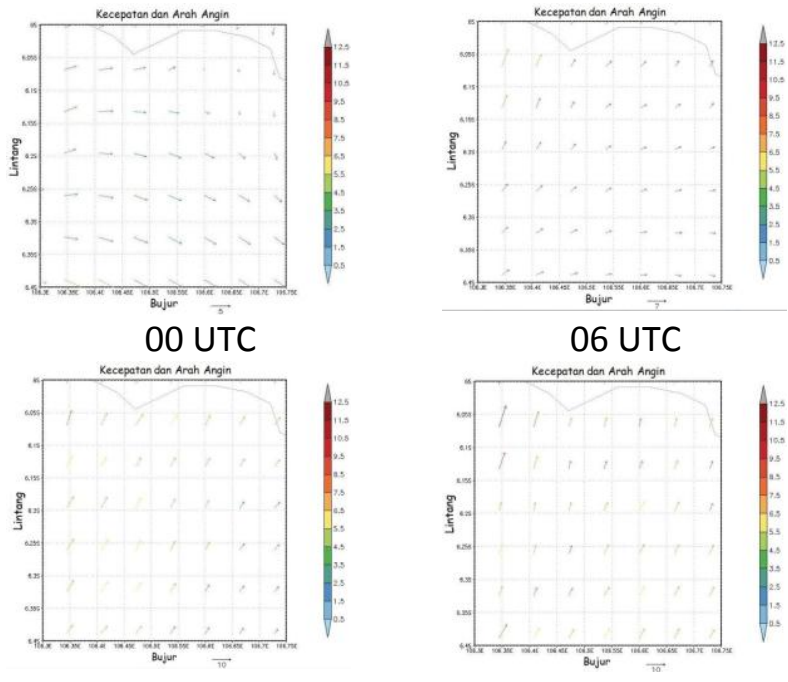

12 UTC

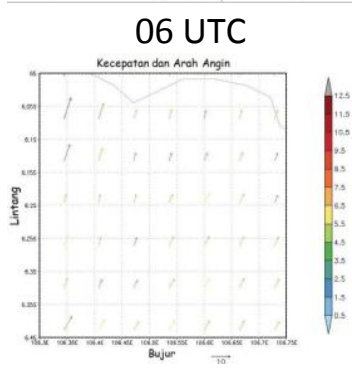

18 UTC

(b)

(b) 
Lampiran 3 Sebaran konsentrasi PM10 $\left(\mu^{-3} \mathrm{~m}^{-3}\right)(\mathrm{a})$ dan pola angin (b) tanggal 30 Juli 2013 tiap enam jam di Kabupaten Tangerang

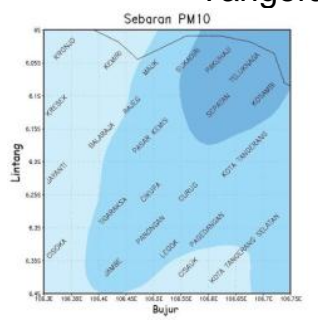

OO UTC

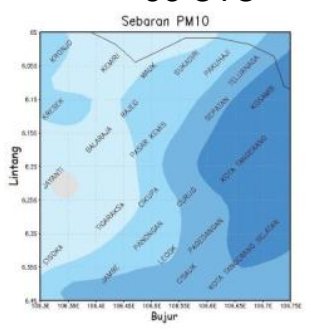

12 UTC
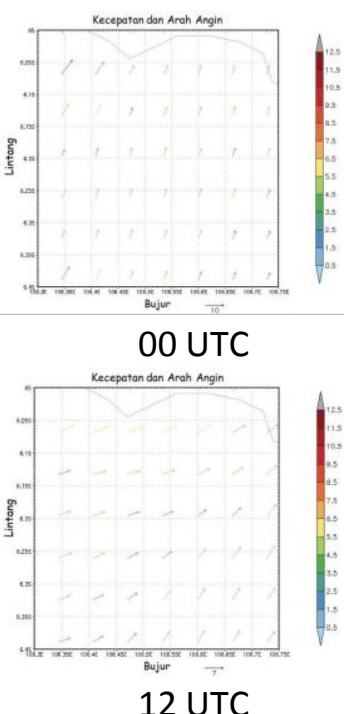

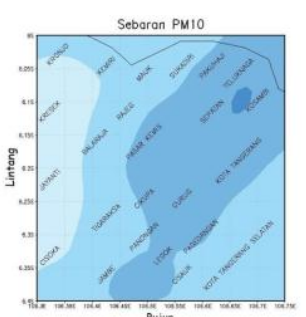

06 UTC

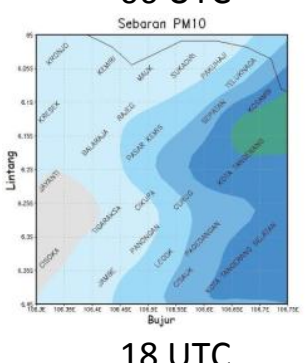

(a)

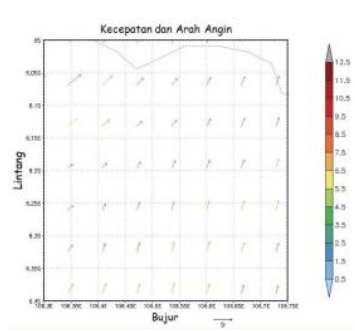

06 UTC

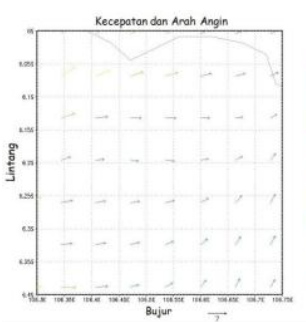

18 UTC
Lampiran 4 Sebaran konsentrasi PM10 $\left(\mu \mathrm{g} \mathrm{m}^{-3}\right)(\mathrm{a})$ dan pola angin (b) tanggal 31 Juli 2013 tiap enam jam di Kabupaten Tangerang
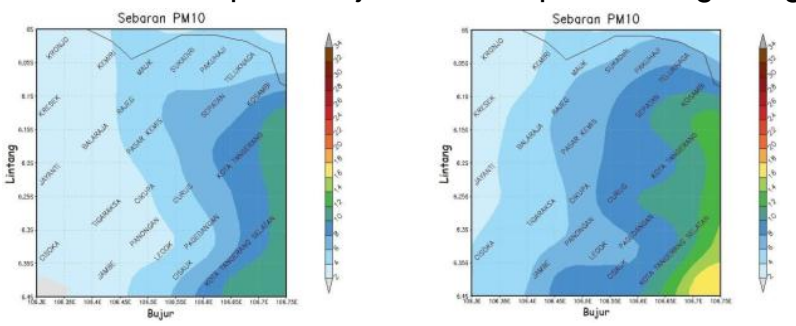

OO UTC

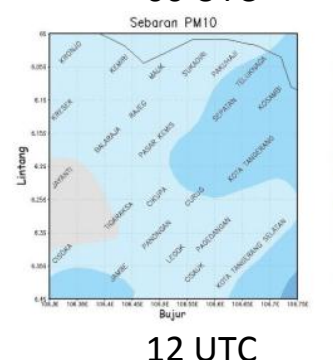

06 UTC

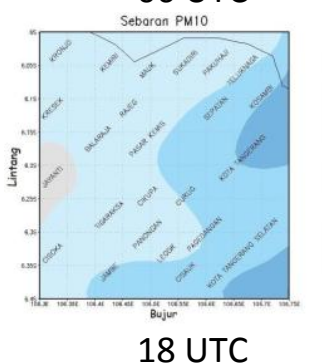

(a)
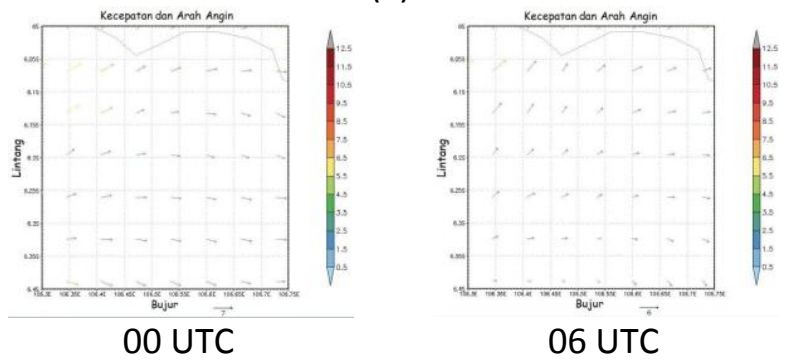

06 UTC

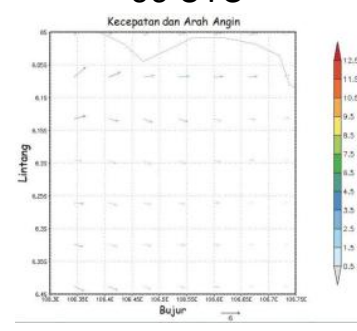

18 UTC

(b) 
Lampiran 5 Sebaran konsentrasi PM10 $\left(\mu \mathrm{g} \mathrm{m}^{-3}\right)(\mathrm{a})$ dan pola angin (b) tanggal 1 Agustus 2013 tiap enam jam di Kabupaten
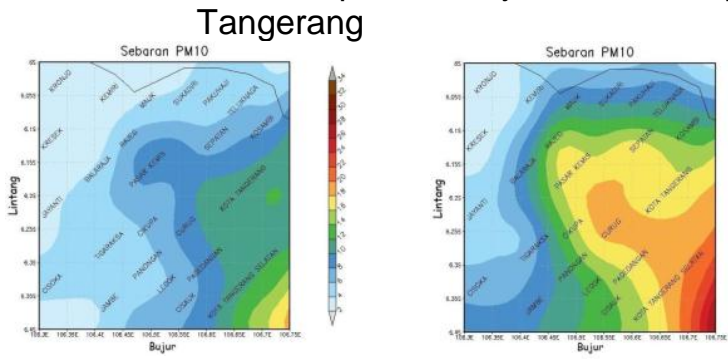

00 UTC

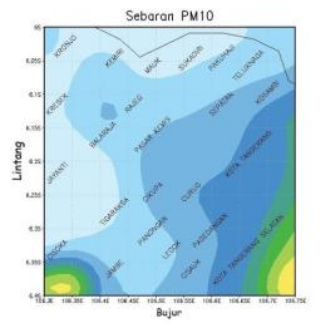

12 UTC
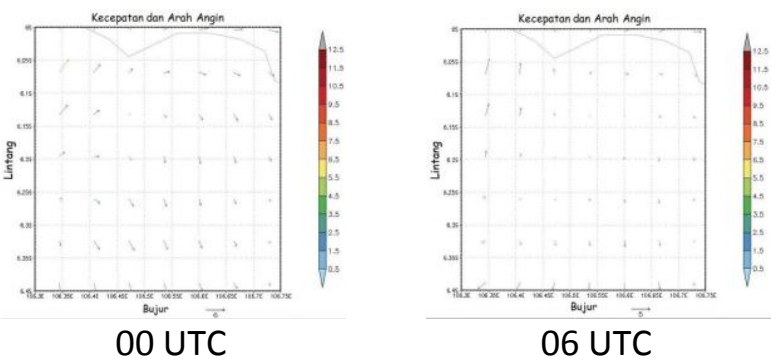

00 UTC

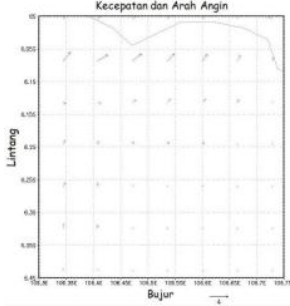

12 UTC (b)

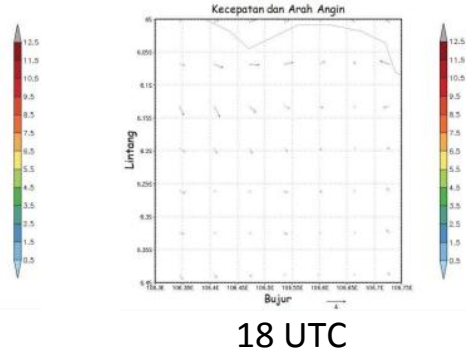

(a) 
Lampiran 6 Data kondisi meteorologi pada lima hari pemantauan

\begin{tabular}{|c|c|c|c|c|c|c|c|}
\hline $\begin{array}{l}\text { Nama } \\
\text { Stasiun }\end{array}$ & Tanggal & $\begin{array}{l}\text { Suhu } \\
\text { Min. } \\
\left({ }^{\circ} \mathrm{C}\right)\end{array}$ & $\begin{array}{l}\text { Suhu } \\
\text { Maks. } \\
\left({ }^{\circ} \mathrm{C}\right)\end{array}$ & $\begin{array}{l}\text { Suhu } \\
\text { Rata- } \\
\text { rata } \\
\left({ }^{\circ} \mathrm{C}\right) \\
\end{array}$ & $\begin{array}{c}\text { Kelembaban } \\
\text { Rata-rata } \\
(\%)\end{array}$ & $\begin{array}{l}\text { Hujan } \\
(\mathrm{mm})\end{array}$ & $\begin{array}{l}\text { Sunshine } \\
\text { (Jam) }\end{array}$ \\
\hline BUDIARTO & & & & & & & \\
\hline $\begin{array}{l}\text { CURUG } \\
\text { BUDIARTO }\end{array}$ & $28 / 07 / 2013$ & 23 & 31.5 & 27 & 79 & 8888 & 4.2 \\
\hline $\begin{array}{l}\text { CURUG } \\
\text { BUDIARTO }\end{array}$ & 29/07/2013 & 22.8 & 31.8 & 26.1 & 88 & 4.5 & 3 \\
\hline $\begin{array}{l}\text { CURUG } \\
\text { BUDIARTO }\end{array}$ & $30 / 07 / 2013$ & 22.2 & 30.2 & 24.6 & 92 & 62.4 & 4.2 \\
\hline $\begin{array}{l}\text { CURUG } \\
\text { BUDIARTO }\end{array}$ & $31 / 07 / 2013$ & 23 & 30.4 & 26.1 & 80 & 0 & 3.3 \\
\hline CURUG & $01 / 08 / 2013$ & 23.2 & 31.8 & 26.2 & 84 & 1.3 & 5.8 \\
\hline
\end{tabular}

Keterangan :

$8888=$ tak terukur

Blank = tidak ada data

Lampiran 7 Rataan konsentrasi PM10 dan kecepatan angin

\begin{tabular}{rrr}
\hline Waktu & $\begin{array}{c}\text { Rataan } \\
\text { Konsentrasi } \\
\text { PM10 }\left(\mu \mathrm{g} \mathrm{m}^{-3}\right)\end{array}$ & $\begin{array}{c}\text { Rataan } \\
\text { Kecepatan } \\
\text { Angin }\left(\mathrm{m} \mathrm{s}^{-1}\right)\end{array}$ \\
\hline 1 & 6.2 & 10.3 \\
7 & 8.1 & 6.5 \\
13 & 6.4 & 9.2 \\
19 & 6.7 & 11 \\
25 & 8 & 8.9 \\
31 & 8.7 & 10 \\
37 & 3.8 & 14.2 \\
43 & 4.5 & 19.4 \\
49 & 4.6 & 22.7 \\
55 & 5.5 & 23.8 \\
61 & 5.5 & 22.6 \\
67 & 5 & 22.1 \\
73 & 5.1 & 20 \\
79 & 7.1 & 16.9 \\
85 & 3.4 & 17.2 \\
91 & 3.7 & 16.5 \\
97 & 6.5 & 15.7 \\
103 & 11.7 & 15.7 \\
109 & 6.1 & 16 \\
115 & 7.5 & 15.5 \\
\hline
\end{tabular}

